\title{
Changes in Tear-Film Status and Ocular Surface Disease Index Score Following Prolonged Use of Face Mask
}

\author{
Nawreen Binte Anwar1 ${ }^{*}$, Basil Anwar², Arup Krishna Choudhury ${ }^{3}$, Mahfuza Rahman Khan4, \\ Md. Anisur Rahman ${ }^{5}$ \\ ${ }^{1}$ Bangabandhu Sheikh Mujib Medical University, Dhaka, Bangladesh \\ ${ }^{2}$ National Institute of Ophthalmology \& Hospital, Dhaka, Bangladesh \\ ${ }^{3}$ Department of Vitreo-Retina, Ispahani Islamia Eye Institute \& Hospital, Dhaka, Bangladesh \\ ${ }^{4}$ Department of Ophthalmology, Combined Military Hospital, Dhaka, Bangladesh \\ ${ }^{5}$ Department of Ophthalmology, Dhaka Medical College \& Hospital, Dhaka, Bangladesh \\ Email: *snawreen18@gmail.com
}

How to cite this paper: Anwar, N.B., Anwar, B., Choudhury, A.K., Khan, M.R. and Rahman, Md.A. (2021) Changes in TearFilm Status and Ocular Surface Disease Index Score Following Prolonged Use of Face Mask. Open Journal of Ophthalmology, 11, 253-265.

https://doi.org/10.4236/ojoph.2021.114021

Received: September 18, 2021

Accepted: October 29, 2021

Published: November 1, 2021

Copyright $\odot 2021$ by author(s) and Scientific Research Publishing Inc. This work is licensed under the Creative Commons Attribution International License (CC BY 4.0).

http://creativecommons.org/licenses/by/4.0/

\begin{abstract}
Background: Dry eye is characterized by tear film instability, decreased tear volume and a high Ocular Surface Disease Index (OSDI) score. Face masks have been linked to dry eye complaints in recent studies. Purpose: To evaluate the changes in tear-film status and Ocular Surface Disease Index (OSDI) score following prolonged use of face mask. Design: Cross-sectional study. Method: Patients between 18 to 70 years using masks regularly for at least 2 hours/day for at least 5 days/week from different eye-care centres in Dhaka were included. All subjects were divided into 4 groups. Mask use lasted approximately 2 hours/day in Group 1, 4 hours/day in Group 2, 6 hours/day in Group 3 and 8 hours or more/day in Group 4. Evaluation of symptoms, tearfilm stability and tear volume was done by Ocular Surface Disease Index (OSDI) scores, Tear-film Break-Up Time (TBUT) and Schirmer-1 test. Average of right \& left eye's Tear-film Break Up time (TBUT) and Schirmer-1 value were noted. Results: Total 100 patients were enrolled $(n=100)$. The TBUT $(p<$ $0.001)$ and Schirmer-1 measurement $(\mathrm{p}=0.01)$ were significantly lesser and Ocular Surface Disease Index (OSDI) score were significantly higher in patients using face-masks for longer time $(\mathrm{p}<0.001)$. Conclusion: Patients who wore masks for prolonged time had tear film instability, reduced tear volume and higher Ocular Surface Disease Index (OSDI) score.
\end{abstract}

\section{Keywords}

Tear-Film Break up Time, Schirmer-1, Ocular Surface Disease Index (OSDI), Face-Mask 


\section{Introduction}

The most essential protective element of the ocular surface is the tear film. The secretions from lacrimal glands, accessory lacrimal glands, goblet cells and the meibomian glands make up the tear film [1]. Unstable film, reduced tear volume, hyperosmolar tear and inflammation can lead to dry eye [2]. The prevalence of dry eye is more in Asia specially in underdeveloped and developing countries. Dry Eye Disease depends on numerous risk factors like occupation, socio-economic status, malnutrition etc. In West Bengal and Eastern India, Dry Eye Disease affects roughly $26 \%$ of people over the age of 30 , with a female predominance. According to one study, dry eye affects $35 \%$ to $40 \%$ of Bangladeshi textile workers [3] [4] [5]. Typically, these patients present with grittiness, watering, burning sensation deteriorating over the course of the day, stringy discharge, transient blurring vision and ocular discomfort. Dry eye has association with many physiological factors (e.g. aging, menopause), pathological factors (e.g. Sjogren syndrome, lacrimal deficiency, meibomian gland deficiency, Diabetes Mellitus, Hashimoto's thyroiditis etc.), iatrogenic factors (contact lens, drugs, ophthalmic surgery etc.) and environmental factors (e.g. prolonged screen time, air conditioner, smokers etc.) [6]-[15].

Many studies have demonstrated that Dry Eye Disease, like other chronic conditions, can reduce one's quality of life. So, it is essential to diagnose and identify the pathology for proper management. Both subjective and objective evaluation is needed as the signs and symptoms often do not co-relate [16] [17] [18].

Since the declaration of COVID-19 as global pandemic, facemasks have been made mandatory all over the world to prevent the spread of the virus. As people have been wearing facemasks for several hours on a regular basis for more than a year, a significant rise of dry eye symptoms has been noticed in the Ophthalmology out-patient department throughout the world. This observation was first made by Dr. D. E. White, an American Ophthalmologist in June 2020. He named this condition as "Mask Associated Dry Eye" (MADE) [19] [20].

Some studies have predicted that people wearing facemasks for a prolonged period have been diagnosed with Dry Eye Disease due to tear film and eye-lid abnormalities [21]-[26]. Very few studies with small sample size have been done to evaluate the tear film status in face-mask wearers. The purpose of this study was to determine the status of the tear film and dry eye symptoms in mask wearers, which would serve as a foundation for future research on the topic and aid in the provision of evidence-based care to patients.

\section{Materials and Methods}

\subsection{Participants}

Patients aged 18 to 70 years who attended different eye-care centers in Dhaka city between February 1, 2021 and August 31, 2021 and wore facemasks for at least 2 hours/day for at least 5 days/week were included in this cross-sectional 
study after sufficient consent was obtained. Non-randomized purposive sampling was done. Contact lens users, patients with history of refractive or intraocular surgery, Sjögren's syndrome, rheumatoid arthritis, parkinsonism, Lupus, previously diagnosed with dry eye or ocular surface disorder, anti-histamines and diuretics takers were excluded.

\subsection{Methods of Assessment}

The main outcome variables were TBUT, tear volume measured by Schirmer-1 and OSDI score of the subjects. Old age, female gender, prolonged screen-time, Diabetes Mellitus were potential confounders. After taking informed consent, relevant questions were asked to detect these risk factors. The duration of face mask use was used to split all subjects into 4 groups. The duration of wearing face-masks in Group 1 was around 2 hours/day, Group 2 was around 4 hours/day, Group 3 was around 6 hours/day and in Group 4 it was 8 hours or more/day on at least 5 days a week. The findings of the groups were compared to each other. The Ocular Surface Disease Index questionnaire (OSDI) was used to assess the symptomatology, and the scores were recorded. The Tear-film Break-Up Time (TBUT) and Schirmer-1 test was used to determine tear-film stability and tear volume respectively. The average of the right and left eye's result was used to create a single value. Relevant questions were asked to the patient to assess the risk factors of dry eye. The Schirmer-1 test was performed using a Schirmer paper strip $(5 \times 35 \mathrm{~mm})$ and the length of wetting from the notch was recorded after 5 minutes. The cut off value for wetting was $<10 \mathrm{~mm} / 5 \mathrm{~min}$ [27] [28]. TBUT was measured by instilling fluorescein $2 \%$ eye drops into the lower fornix. After several blinks, the interval between the last blink and appearance of first dry spot was noted. Less than 10 seconds TBUT was considered abnormal [29] [30]. The overall Ocular Surface Disease Index (OSDI) score was divided into four categories: normal ocular surface ( 0 - 12 points), mild (13 - 22 points), moderate (23 32 points), and severe (33 - 100 points) [31].

\subsection{Statistical Methods}

Continuous variables were reported as mean \pm SD. ANOVA and the Wilcoxon rank-sum test were used to compare groups. The Chi-square test or Fisher's exact test were used to compare categorical variables, which were reported as proportions. Confounders that might predict changes in TBUT, tear volume, and OSDI score in various groups were identified using univariate and multivariate regression. All of the data was imported into Microsoft Excel and analyzed with SPSS version 22.

\section{Results}

In this study, we assessed 167 patients for eligibility initially. Sixty-five patients did not meet all the inclusion and exclusion criteria and 2 patients declined to participate. Hundred patients were finally confirmed as eligible $(n=100)$. The 
difference among the demographics and baseline characteristics of the groups was not statistically significant; except for the male-female ratio $(p=0.02)$. Age of the patients, number of the diabetics and patients with long screen time in all 4 groups were almost similar (Table 1 ). The overall TBUT was $13.84 \pm 1.84$ seconds, Schirmer-1 was $21.18 \pm 5 \mathrm{~mm}$ in 5 minutes and OSDI was $17.47 \pm$ 15.18. Figure 1 and Figure 2 shows distribution of TBUT \& Schirmer-1 measurement of all the groups with their different durations of wearing mask.

The difference among the groups' tear film stability which was assessed by TBUT, tear volume measured by Schirmer-1 and OSDI score was statistically significant (Table 2). The TBUT was shorter in groups with history of longer duration of face-mask use $(\mathrm{p}<0.001)$. Schirmer 1 measurement also reduced significantly with the increasing hours of using face-mask ( $\mathrm{p}=0.01$ ). Also, the Ocular Surface Disease Index (OSDI) score were significantly higher in patients who wore face-masks for longer time $(\mathrm{p}<0.001)$. So, there was a positive correlation of OSDI and negative correlations of TBUT \& tear volume (Schirmer-1) with the amount of duration wearing face-masks (Figures 3-5). Univariate regression analysis revealed for every 15 years increment in age, TBUT decreased by $0.5 \mathrm{sec}(\mathrm{p}=0.002)$, Schirmer-1 reduced by $3.6 \mathrm{~mm} .(\mathrm{p}<0.001)$ and OSDI

Table 1. Demography of study population and inter-group comparison of baseline characteristics.

\begin{tabular}{ccccccc}
\hline Variable & $\begin{array}{c}\text { Total } \\
(\mathbf{n}=100)\end{array}$ & $\begin{array}{c}\text { Group 1 } \\
(\mathbf{n = 2 8})\end{array}$ & $\begin{array}{c}\text { Group 2 } \\
(\mathbf{n}=\mathbf{2 3})\end{array}$ & $\begin{array}{c}\text { Group 3 } \\
(\mathbf{n}=19)\end{array}$ & $\begin{array}{c}\text { Group 4 } \\
(\mathbf{n}=30)\end{array}$ & $\begin{array}{c}\mathbf{P} \\
\text { value }\end{array}$ \\
\hline Age (Mean \pm SD) years & $46.5 \pm 14.9$ & $47.1 \pm 17.9$ & $47.8 \pm 15.6$ & $48 \pm 11.4$ & $44.1 \pm 13.7$ & 0.76 \\
Male, n (\%) & $47(47 \%)$ & $16(57.1 \%)$ & $15(65.2 \%)$ & $4(21.05 \%)$ & $12(40 \%)$ & 0.02 \\
Diabetic & $23(23 \%)$ & $5(17.9 \%)$ & $7(30.4 \%)$ & $4(21.05 \%)$ & $7(23.33 \%)$ & 0.78 \\
Long screen time & $84(84 \%)$ & $21(75 \%)$ & $18(78.3 \%)$ & $17(89.5 \%)$ & $28(93.3 \%)$ & 0.2 \\
\hline
\end{tabular}

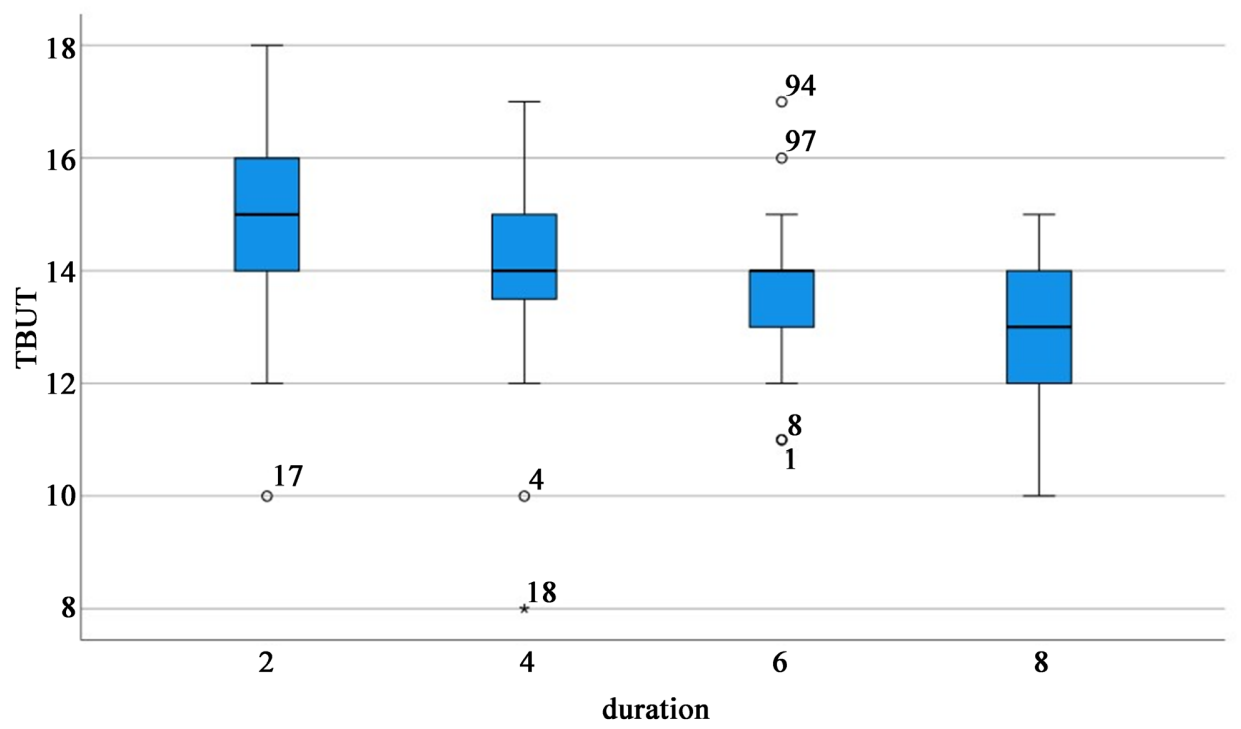

Figure 1. The median TBUT (sec) with interquartile range and outliers of 4 groups shown in a box and whisker plot. 


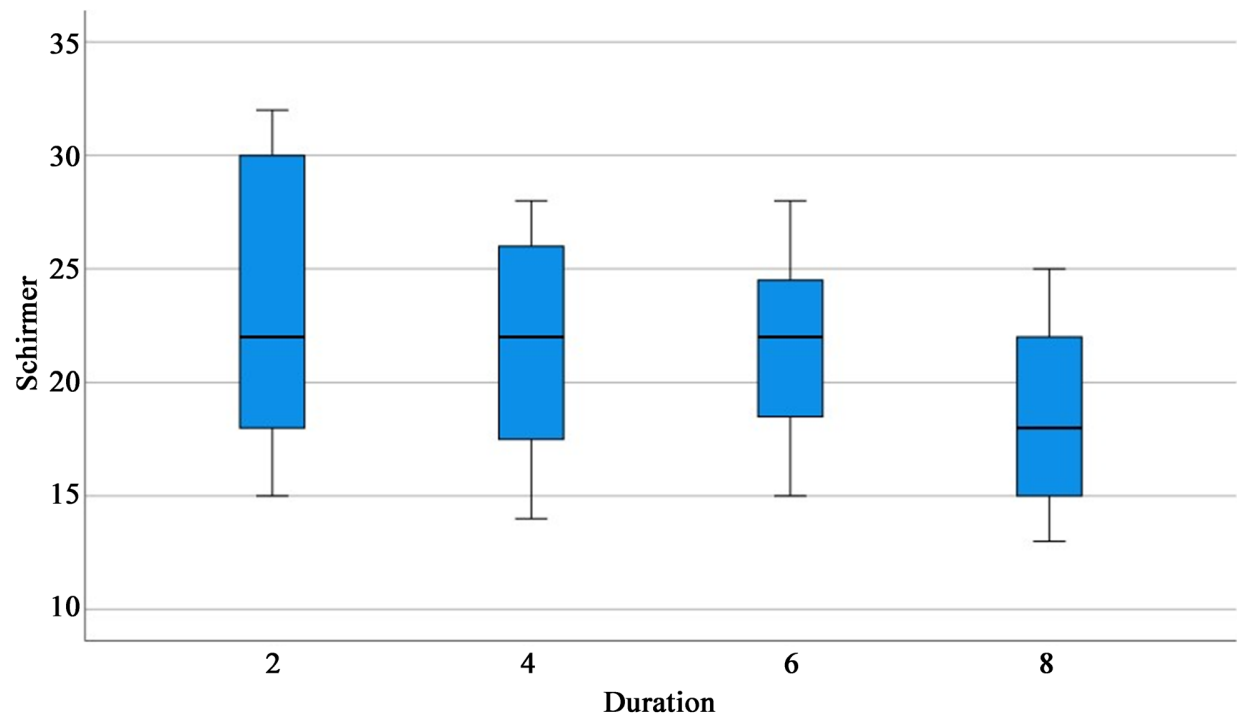

Figure 2. Median Schirmer 1 measurement with interquartile range \& outliers of 4 groups shown in a box and whisker plot.

Table 2. Inter-group comparison of changes in TBUT, Schirmer-1 measurement and OSDI score $(n=100)$.

\begin{tabular}{cccccc}
\hline Variable & $\begin{array}{c}\text { Group 1 } \\
(\mathrm{n}=28)\end{array}$ & $\begin{array}{c}\text { Group 2 } \\
(\mathrm{n}=23)\end{array}$ & $\begin{array}{c}\text { Group 3 } \\
(\mathrm{n}=19)\end{array}$ & $\begin{array}{c}\text { Group 4 } \\
(\mathrm{n}=30)\end{array}$ & $\begin{array}{c}\mathbf{P} \\
\text { value }\end{array}$ \\
\hline $\begin{array}{c}\text { Mean TBUT } \pm \text { SD }(\mathrm{sec}) \\
\text { Mean Schirmer-1 measurement } \\
\pm \text { SD (mm in 5 min) }\end{array}$ & $14.8 \pm 1.8$ & $14.2 \pm 2.1$ & $13.6 \pm 1.5$ & $12.8 \pm 1.2$ & $<0.001$ \\
$\begin{array}{c}\text { Mean OSDI score } \pm \text { SD } \\
\text { Men }\end{array}$ & $11.8 \pm 14.2$ & $16.1 \pm 15.6$ & $19.6 \pm 14.9$ & $22.5 \pm 14.7$ & $<0.001$ \\
\hline
\end{tabular}

TBUT: Tear-film Break-Up Time, OSDI: Ocular Surface Disease Index.

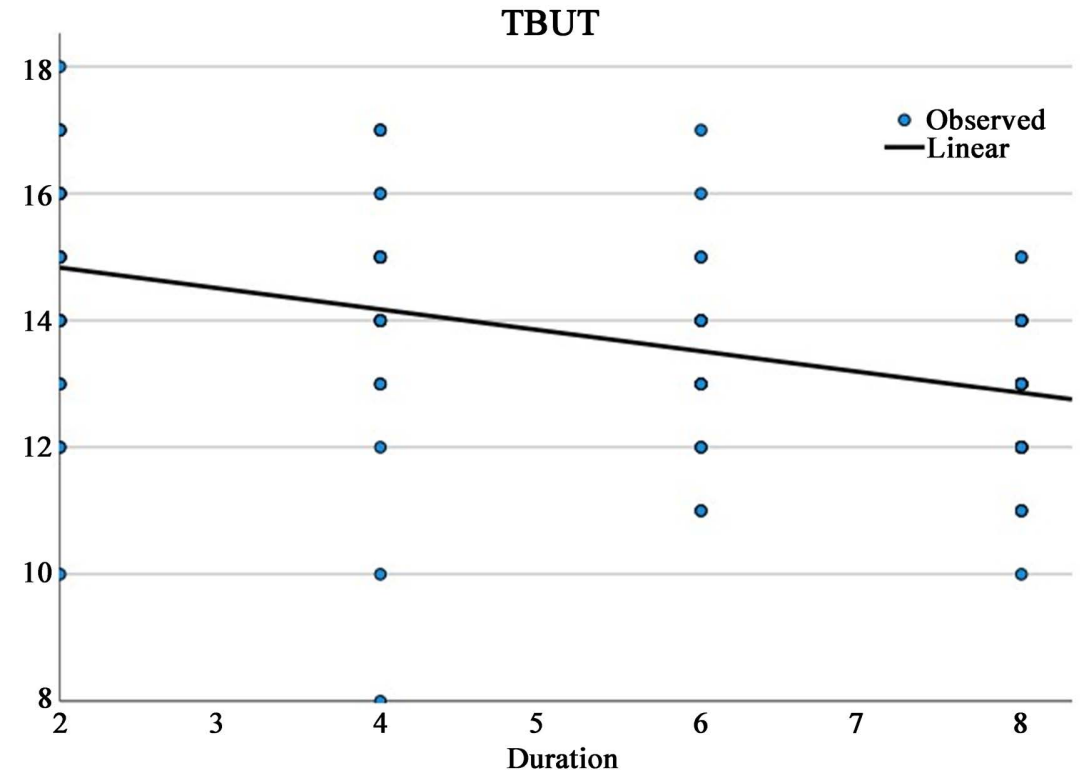

Figure 3. Linear graph showing negative correlation between duration of facemask use and TBUT (Pearson correlation $=-0.427$ ). 


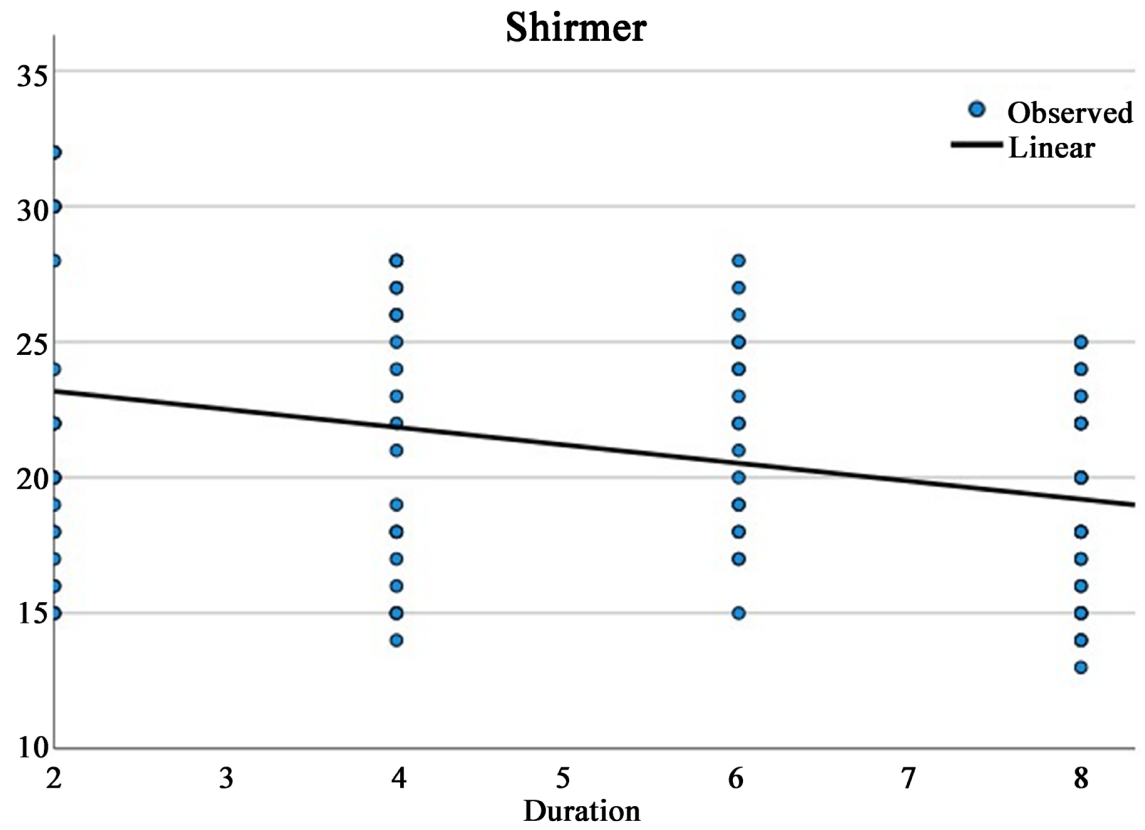

Figure 4. Linear graph showing negative correlation between duration of facemask use and Schirmer-1 measurement (Pearson correlation $=-0.315)$.

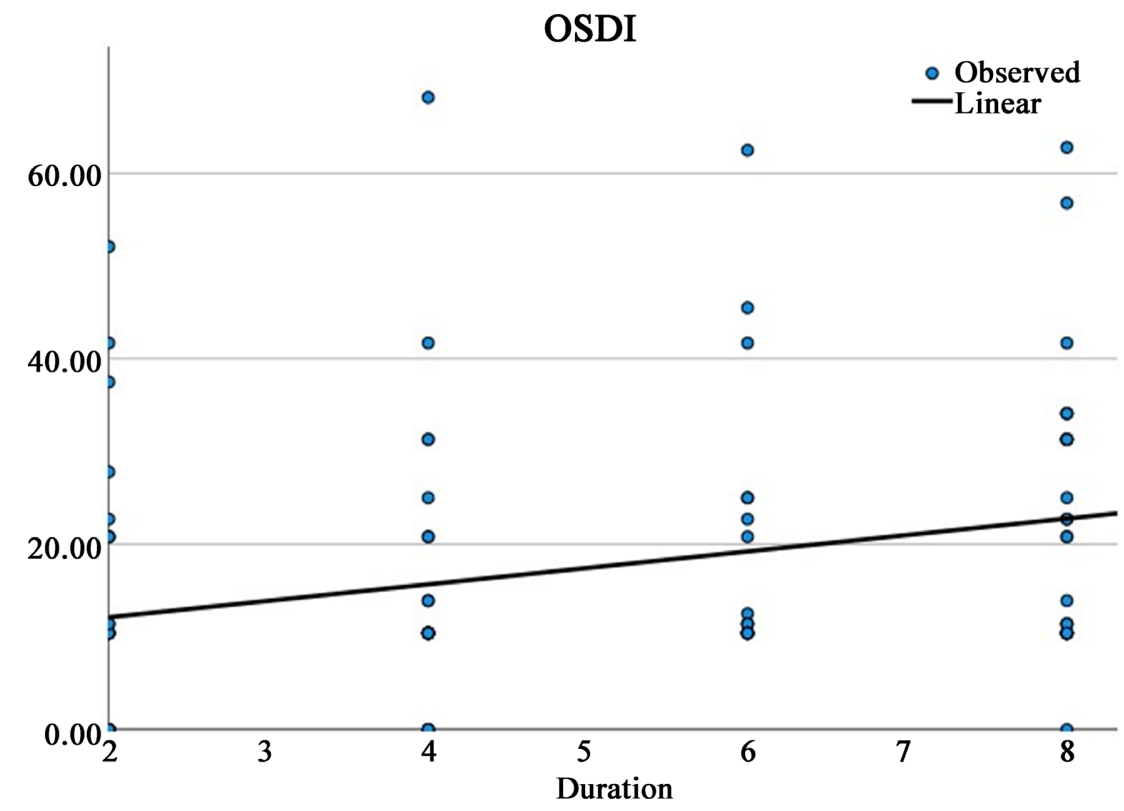

Figure 5. Linear graph showing positive correlation between duration of facemask use and OSDI score (Pearson correlation $=0.279$ ).

score will increase by $7.6(\mathrm{p}<0.001)$. Being diabetic increased TBUT by 0.4 seconds $(\mathrm{p}=0.047)$, Schirmer-1 by $2.01 \mathrm{~mm}(\mathrm{p}<0.001)$ and reduced OSDI score by 5.1. $(p=0.001)$. For every 2.4 hours increase in the duration of wearing masks, TBUT decreased by $0.8 \mathrm{sec}(\mathrm{p}<0.001)$, tear volume decreased by $1.6 \mathrm{~mm}$ $(\mathrm{p}=0.001)$ and OSDI score increased by $4.2(\mathrm{p}=0.005)$. But multivariate analysis revealed, every 15 years increase in age decreased TBUT by $0.6 \mathrm{sec}(\mathrm{p}=$ 0.003), reduced Schirmer-1 by $3.7 \mathrm{~mm}(\mathrm{p}<0.001)$, increased OSDI score by 7.1. 
$(\mathrm{p}<0.001)$. With every 2.4 hours increase in mask usage per day TBUT decreased by $0.8 \mathrm{sec}(\mathrm{p}<0.001)$, Schirmer-1 reduced by $1.97 \mathrm{~mm}(\mathrm{p}<0.001)$ and OSDI score increased by $4.81(\mathrm{p}<0.001)$. Changes due to prolonged screen time and female gender among groups were not statistically significant (Table 3 ).

\section{Discussion}

In this cross-sectional study, we evaluated the changes in tear-film status and Ocular Surface Disease Index (OSDI) score due to prolonged use of face mask. We found that people wearing face-masks for longer period had tear-film instability, reduced tear volume and were more symptomatic. In groups with longer mask wearing time, the mean Tear-film Break-Up Time (TBUT) was shorter, the Schirmer-1 result was lower and the Ocular Surface Disease Index (OSDI) score was substantially higher than in groups with mask wearing time of 2 hours or less per day. With the increment in the duration of using masks, the results of the parameters tested worsened. We also found older age and Diabetes Mellitus negatively affects tear film stability, tear volume and Ocular Surface Disease Index (OSDI) score.

The Dry Eye Workshop (DEWS) committee has identified increased osmolarity and instability of tear-fim as the fundamental causes of Dry Eye Disease [32]. Similar to our study, Moshirfar [21] found worsening of corneal staining indicating loss of tear-film integrity in regular mask-wearers. Although they did not evaluate tear volume like our study, the study inculpated the evaporation of tear-film as the etiology of tear-film instability. Salami [33] conducted a study where AS-OCT of the tear meniscus (TM) were done at baseline and after 8 hours of wearing protective masks. There was $23 \%$ reduction in tear meniscus

Table 3. Univariate and multi-variate regression analysis to detect factors influencing tear film status and OSDI score

\begin{tabular}{|c|c|c|c|c|c|c|}
\hline \multirow{2}{*}{$\begin{array}{l}\text { Variable with } \\
\text { Interval }\end{array}$} & \multicolumn{3}{|c|}{ Univariate analysis $\beta$ coefficient $(95 \% \mathrm{CI})$} & \multicolumn{3}{|c|}{ Multivariate analysis $\beta$ coefficient $(95 \% \mathrm{CI})$} \\
\hline & TBUT & $\begin{array}{l}\text { Schirmer-1 } \\
\text { measurement }\end{array}$ & OSDI score & TBUT & $\begin{array}{l}\text { Schirmer-1 } \\
\text { measurement }\end{array}$ & OSDI score \\
\hline $\begin{array}{l}2.4 \text { hours/day } \\
\text { increment } \\
\text { in mask use }\end{array}$ & $\begin{array}{c}-0.43 \\
(-0.47 \text { to }-0.19)^{\star * *}\end{array}$ & $\begin{array}{c}-0.32 \\
(-1.06 \text { to }-0.26)^{\star *}\end{array}$ & $\begin{array}{c}0.279 \\
(0.55 \text { to } 2.99)^{\star *}\end{array}$ & $\begin{array}{c}-0.46 \\
(-0.5 \text { to }-0.21)^{\star * *}\end{array}$ & $\begin{array}{c}-0.39 \\
(-1.1 \text { to }-0.56)^{* * *}\end{array}$ & $\begin{array}{c}0.32 \\
(0.92 \text { to } 3.11)^{\star * *}\end{array}$ \\
\hline $\begin{array}{c}15 \text { years } \\
\text { increment in } \\
\text { age }\end{array}$ & $\begin{array}{c}-0.31 \\
(-0.06 \text { to }-0.01)^{\star *}\end{array}$ & $\begin{array}{c}-0.71 \\
(-0.29 \text { to }-1.89)^{\star * *}\end{array}$ & $\begin{array}{c}0.5 \\
(0.33 \text { to } 0.68)^{* * *}\end{array}$ & $\begin{array}{c}-0.32 \\
(-0.07 \text { to }-0.01)^{\star *}\end{array}$ & $\begin{array}{c}-0.75 \\
(-0.3 \text { to }-0.2)^{\star * *}\end{array}$ & $\begin{array}{c}0.47 \\
(0.28 \text { to } 0.69)^{* * *}\end{array}$ \\
\hline Male Vs Female & $\begin{array}{c}-0.13 \\
(-1.19 \text { to } 0.27)\end{array}$ & $\begin{array}{c}-0.05 \\
(-2.55 \text { to } 1.46)\end{array}$ & $\begin{array}{c}0.11 \\
(-2.71 \text { to } 9.34)\end{array}$ & $\begin{array}{c}-0.03 \\
(-0.75 \text { to } 0.56)\end{array}$ & $\begin{array}{c}0.06 \\
(-0.72 \text { to } 1.84)\end{array}$ & $\begin{array}{c}0.04 \\
(-4.0 \text { to } 6.33)\end{array}$ \\
\hline $\begin{array}{c}\text { Diabetic Vs } \\
\text { Non-diabetic }\end{array}$ & $\begin{array}{c}0.2 \\
(0.01 \text { to } 1.72)^{\star}\end{array}$ & $\begin{array}{c}0.4 \\
(2.45 \text { to } 6.8)^{\star \star \star \star}\end{array}$ & $\begin{array}{c}-0.34 \\
(-18.86 \text { to }-5.3)^{\star \star}\end{array}$ & $\begin{array}{c}0.02 \\
(-0.84 \text { to } 0.97)\end{array}$ & $\begin{array}{c}-0.03 \\
(-2.13 \text { to } 1.42)\end{array}$ & $\begin{array}{c}-0.08 \\
(-9.88 \text { to } 4.43)\end{array}$ \\
\hline $\begin{array}{c}\text { Long screen } \\
\text { time Vs no or } \\
\text { less screen time }\end{array}$ & $\begin{array}{c}-0.007 \\
(-1.03 \text { to } 0.97)\end{array}$ & $\begin{array}{c}-0.098 \\
(-4.05 \text { to } 1.39)\end{array}$ & $\begin{array}{c}0.072 \\
(-5.28 \text { to } 11.21)\end{array}$ & $\begin{array}{c}-0.05 \\
(-1.12 \text { to } 0.67)\end{array}$ & $\begin{array}{c}-0.04 \\
(-2.23 \text { to } 1.24)\end{array}$ & $0.05(-4.9$ to 9.22$)$ \\
\hline
\end{tabular}

$\mathrm{p}<0.05^{\star}, \mathrm{p}<0.01^{\star *}, \mathrm{p}<0.001^{\star * *}$; TBUT: Tear-film Break-Up Time, OSDI: Ocular Surface Disease Index. 
height and 39.4\% reduction in tear meniscus area. Reduced tear meniscus height indicates reduced tear volume. It has been detected that exhaled $\mathrm{CO}_{2}$ rich air has the temperature of $36^{\circ} \mathrm{C}-37^{\circ} \mathrm{C}$. It has been hypothesized, this warm, humid air escapes through the upper gap of the mask and directly increases the osmolarity and hampers tear-film stability by evaporating the tear-film [34]. A prospective study by Mustafa Aksoy [35] evaluated 52 subjects who regularly wore masks for at least 8 hours/day. Mean Tear Break Up Time (TBUT) and Schirmer-1 was reduced after 8 hours of wearing masks without taping $(\mathrm{p}<0.001)$. But, interestingly, after wearing taped masks for 8 hours/day for 15 days, the mean TBUT and Schirmer-1 were similar to the baseline results $(\mathrm{p}<0.001)$. It seems preventing the contact of expired warm air with ocular surface helped to preserve tear-film stability and volume. One study showed, low air humidity can cause tear-film hyper-osmolarity [36] [37]. Again, the findings of these studies support the hypothesis of tear-film evaporation due to exhaled warm air passing through the upper opening of mask.

Like many previous notable research, in our study we found Ocular Surface Disease Index (OSDI) score was positively correlated with the duration of mask usage. Evelina Marinova [26] reported similar correlation and increased dry eye symptoms in people wearing masks for more than 6 hours/day. People using heavy medical masks were more symptomatic. Similarly, when Scalinci [38] compared the Ocular Surface Disease Index (OSDI) scores of 67 subjects 1 year apart, the median difference of the score was significantly higher in heavy mask users ( $>6$ hours/day mask usage).

Many studies have stated that high $\mathrm{CO}_{2}$ level in the tear-film causes reduction of $\mathrm{p}^{\mathrm{H}}$ in the corneal stroma that stimulates nociceptors and ultimately leads to exacerbation of dry eye symptoms. This $\mathrm{CO}_{2}$ also causes hypoxia and inflammation by producing reactive oxygen species, pro-inflammatory factors and leucocytes [39]-[45]. Supporting these findings, Mastropasqua [46] ascertained that use of face-masks for more than 3 months deteriorated Quality of Life (QOL) score, Tear Break-Up Time, ocular surface staining, raised cellular and molecular markers of inflammation like Dendritic Cell Density (DCD) and HLADR. The changes were more evident in previously diagnosed dry eye patients. They pointed out that TBUT was decreased as a result of inflammation and mucin loss rather than reduced Goblet Cell Density (GCD). Tight mask induced ectropion, incomplete blinking and air regurgitation through nasolacrimal duct have also been suggested for decreased tear film turn-over [47]. Dry eye symptoms were also found in COVID-19 patients. But the studies were not conclusive about whether it was due to ocular complications of COVID-19 or mask use [48]. So, it can be said that evaporation of tear-film, inflammatory mediators, mechanical effects of tight mask and COVID-19 complications all contribute together to cause Mask Associated Dry Eye (MADE).

On the contrary, many studies have found that women have a higher prevalence of dry eye and report more severe symptoms than men. Estradiol and testosterone levels play a critical role in meibomian gland function, hence meno- 
pausal women are more affected [8] [49] [50] [51]. Because our study population was small and females were underrepresented, the lack of homogeneity may have skewed our findings. Moreover, in this pandemic, online classes and working from home have increased the screen time of most people. Several studies have implicated the association of prolonged screen time with reduction of Tear Break-Up Time due to evaporative type eye dryness [52] [53] [54]. According to studies, diabetics have hyperosmolar tear films due to hyperglycemia, decreased aqueous secretion due to microangiopathy of the lacrimal gland arteries and corneal nerve neuropathy. Our findings may have been influenced by the fact that we did not consider the glycaemic status of our diabetic individuals in this investigation [55] [56].

Our study surely had some other limitations which may have acted as potential bias; which includes unequal group size, absence of control group with no history of wearing masks. In addition, as this study was cross sectional, the divided groups were entirely based on the subjective feedback of the patients on duration of wearing masks. There was no strict monitoring on the number of hours using facemask.

In this pandemic era, the use of face-mask is undoubtedly mandatory to prevent spreading and protect oneself from COVID-19. Ophthalmologists should be aware that Dry Eye Disease may be caused or aggravated by regular prolonged use of masks and should examine the tear-film of the risk group as a part of routine check-up. Early diagnosis of Dry Eye Disease is essential as untreated conditions can affect one's quality of life and most importantly vision. Further studies with large sample size are required to investigate the bio-chemical changes in tear-film and Dry Eye Disease in mask users; so that it can be prevented.

\section{Conclusion}

In this study, patients wearing masks for longer time had tear film instability, reduced tear volume and higher Ocular Surface Disease Index (OSDI) score, which indicates the association of dry eye with prolonged use of face-mask.

\section{Conflicts of Interest}

The authors declare no conflicts of interest regarding the publication of this paper.

\section{References}

[1] Biber, J.M. (2013) Ocular Surface Disease: Cornea, Conjunctiva and Tear Film. Elsevier, Amsterdam.

[2] Craig, J., Nichols, K., Akpek, E., Caffery, B., Dua, H., Joo, C.-K., Liu, Z., Nelson, D., Nichols, J.J., Tsubota, K. and Stepleton, F. (2017) TFOS DEWS II Definition and Classification Report. The Ocular Surface, 15, 276-283. https://doi.org/10.1016/j.jtos.2017.05.008

[3] Basak, S.K., Pal, P.P., Basak, S., Bandyopadhyay, A., Choudhury, S. and Sar, S. (2012) 
Prevalence of Dry Eye Diseases in Hospital-Based Population in West Bengal, Eastern India. Journal of the Indian Medical Association, 110, 789-794.

[4] Rashid, M.A., Teo, C., Mamun, S., Ong, H.S. and Tong, L. (2020) Prevalence and Risk Factors of Severe Dry Eye in Bangladesh-Based Factory Garment Workers. Diagnostics, 10, Article No. 634. https://doi.org/10.3390/diagnostics10090634

[5] Sutradhar, I., Gayen, P., Hasan, M., Gupta, R.D., Roy, T. and Sarker, M. (2019) Eye Diseases: The Neglected Health Condition among Urban Slum Population of Dhaka, Bangladesh. BMC Ophthalmology, 19, Article No. 38. https://doi.org/10.1186/s12886-019-1043-Z

[6] Rizvi, Y., Singh, S. and Dokania, A. (2014) Comparative Assessment of Tear Function and Ocular Surface Following Cataract Surgery Employing Manual SICS and Phacoemulsification Techniques. Indian Journal of Basic and Applied Medical Research, 4, 544-553.

[7] Wang, M., Thomson, W.M. and Craig, J.P. (2020) Association between Symptoms of Xerostomia and Dry Eye in Older People. Contact Lens \& Anterior Eye, 43, 99-102. https://doi.org/10.1016/j.clae.2019.09.002

[8] Peck, T., Olsakovsky, L. and Aggarwal, S. (2017) Dry Eye Syndrome in Menopause and Perimenopausal Age Group. Journal of Mid-Life Health, 8, 51-54.

https://doi.org/10.4103/jmh.JMH 4117

[9] Uchino, M., Yokoi, N., Uchino, Y., Dogru, M., Kawashima, M., Komuro, A., Sonomura, Y., Kato, H., Kinoshita, S., Schaumberg, D.A. and Tsubota, K. (2013) Prevalence of Dry Eye Disease and Its Risk Factors in Visual Display Terminal Users: The Osaka Study. American Journal of Ophthalmology, 156, 759-766.E1.

https://doi.org/10.1016/j.ajo.2013.05.040

[10] Narnoli, P., Dhasmana, R. and Khanduri, R. (2021) Dry Eye Disease and Retinal Nerve Fiber Layer Changes in Chronic Smokers, 69, 1178-1182. https://doi.org/10.4103/ijo.IJO 97620

[11] Gomes, J., Azar, D.T., Baudouin, C., Efron, N., Hirayama, M., Horwath-Winter, J., Kim, T., Mehta, J.S., Messmer, E.M., Pepose, J.S., Sangwan, V.S., Weiner, A.L., Wilson, S.E. and Wolffsohn, J.S. (2017) TFOS DEWS II Iatrogenic Report. The Ocular Surface, 15, 511-538. https://doi.org/10.1016/j.jtos.2017.05.004

[12] Sullivan, D.A., Rocha, E.M., Aragona, P., Clayton, J.A., Ding, J., Golebiowski, B., Hampel, U., McDermott, A.M., Schaumberg, D.A., Srinivasan, S., Versura, P. and Willcox, M. (2017) TFOS DEWS II Sex, Gender, and Hormones Report. The Ocular Surface, 15, 284-333. https://doi.org/10.1016/j.jtos.2017.04.001

[13] Stapleton, F., Alves, M., Bunya, V.Y., Jalbert, I., Lekhanont, K., Malet, F., Na, K.S., Schaumberg, D., Uchino, M., Vehof, J., Viso, E., Vitale, S. and Jones, L. (2017) TFOS DEWS II Epidemiology Report. The Ocular Surface, 15, 334-365. https://doi.org/10.1016/j.jtos.2017.05.003

[14] Graham, A.D., Lundgrin, E.L. and Lin, M.C. (2018) The Berkeley Dry Eye Flow Chart: A Fast, Functional Screening Instrument for Contact Lens-Induced Dryness. PLoS ONE, 13, Article ID: e0190752. https://doi.org/10.1371/journal.pone.0190752

[15] Altin Ekin, M., Karadeniz Ugurlu, S., Egrilmez, E.D. and Oruk, G.G. (2021) Ocular Surface Changes in Hashimoto's Thyroiditis without Thyroid Ophthalmopathy. Eye \& Contact Lens, 47, 32-37. https://doi.org/10.1097/ICL.0000000000000686

[16] Grubbs Jr., J.R., Tolleson-Rinehart, S., Huynh, K. and Davis, R.M. (2014) A Review of Quality of Life Measures in Dry Eye Questionnaires. Cornea, 33, 215-218. https://doi.org/10.1097/ICO.0000000000000038

[17] Sullivan, B.D., Crews, L.A., Messmer, E.M., Foulks, G.N., Nichols, K.K., Baenninger, 
P., Geerling, G., Figueiredo, F. and Lemp, M.A. (2014) Correlations between Commonly Used Objective Signs and Symptoms for the Diagnosis of Dry Eye Disease: Clinical Implications. Acta Ophthalmologica, 92, 161-166.

https://doi.org/10.1111/aos.12012

[18] Cohen, S., Martin, A. and Sall, K. (2014) Evaluation of Clinical Outcomes in Patients with Dry Eye Disease Using Lubricant Eye Drops Containing Polyethylene Glycol or Carboxymethylcellulose. Clinical Ophthalmology, 8, 157-164. https://doi.org/10.2147/OPTH.S53822

[19] Boccardo L. (2021) Self-Reported Symptoms of Mask-Associated Dry Eye: A survey Study of 3,605 People. Contact Lens \& Anterior Eye, Article ID: 101408. Advance Online Publication. https://doi.org/10.1016/j.clae.2021.01.003

[20] Scheid, J.L., Lupien, S.P., Ford, G.S. and West, S.L. (2020) Commentary: Physiological and Psychological Impact of Face Mask Usage during the COVID-19 Pandemic. International Journal of Environmental Research and Public Health, 17, Article No. 6655. https://doi.org/10.3390/ijerph17186655

[21] Moshirfar, M., West Jr., W.B. and Marx, D.P. (2020) Face Mask-Associated Ocular Irritation and Dryness. Ophthalmology and Therapy, 9, 397-400.

https://doi.org/10.1007/s40123-020-00282-6

[22] Matossian, C., Song, X., Chopra, I., Sainski-Nguyen, A. and Ogundele, A. (2020) The Prevalence and Incidence of Dry Eye Disease Among Patients Using Continuous Positive Airway Pressure or Other Nasal Mask Therapy Devices to Treat Sleep Apnea. Clinical Ophthalmology, 14, 3371-3379. https://doi.org/10.2147/OPTH.S274949

[23] Sun, C.B., Wang, Y.Y., Liu, G.H. and Liu, Z. (2020) Role of the Eye in Transmitting Human Coronavirus: What We Know and What We Do Not Know. Frontiers in Public Health, 8, Article No. 155. https://doi.org/10.3389/fpubh.2020.00155

[24] Powell, J.B., Kim, J.H. and Roberge, R.J. (2017) Powered Air-Purifying Respirator Use in Healthcare: Effects on Thermal Sensations and Comfort. Journal of Occupational and Environmental Hygiene, 14, 947-954. https://doi.org/10.1080/15459624.2017.1358817

[25] Dennis, R.J., Miller 2nd., R.E., Peterson, R.D. and Jackson Jr., W.G. (1992) Contact Lens Wear with the USAF Protective Integrated Hood/Mask Chemical Defense Ensemble. Aviation, Space, and Environmental Medicine, 63, 565-571.

[26] Marinova, E., Dabov, D. and Zdravkov, Y. (2020) Ophthalmic Complaints in FaceMask Wearing: Prevalence, Treatment, and Prevention with a Potential Protective Effect against SARS-CoV-2. Biotechnology \& Biotechnological Equipment, 34, 1323 1335. https://doi.org/10.1080/13102818.2020.1838323

[27] Wolffsohn, J.S., Arita, R., Chalmers, R., Djalilian, A., Dogru, M., Dumbleton, K., Gupta, P.K., Karpecki, P., Lazreg, S., Pult, H., Sullivan, B.D., Tomlinson, A., Tong, L., Villani, E., Yoon, K.C., Jones, L. and Craig, J.P. (2017) TFOS DEWS II Diagnostic Methodology Report. The Ocular Surface, 15, 539-574.

https://doi.org/10.1016/j.jtos.2017.05.001

[28] de Monchy, I., Gendron, G., Miceli, C., Pogorzalek, N., Mariette, X. and Labetoulle, M. (2011) Combination of the Schirmer I and Phenol Red Thread Tests as a Rescue Strategy for Diagnosis of Ocular Dryness Associated with Sjögren's Syndrome. Investigative Ophthalmology \& Visual Science, 52, 5167-5173.

https://doi.org/10.1167/iovs.10-6671

[29] F. Salmon, J. (2019) Kanski's Clinical Ophthalmology. 9th Edition, Elsevier, Amsterdam. 
[30] Cuevas, M., González-García, M.J., Castellanos, E., Quispaya, R., Parra, P., Fernández, I. and Calonge, M. (2012) Correlations among Symptoms, Signs, and Clinical Tests in Evaporative-Type Dry Eye Disease Caused by Meibomian Gland Dysfunction (MGD). Current Eye Research, 37, 855-863.

https://doi.org/10.3109/02713683.2012.683508

[31] Miller, K.L., Walt, J.G., Mink, D.R., Satram-Hoang, S., Wilson, S.E., Perry, H.D., Asbell, P.A. and Pflugfelder, S.C. (2010) Minimal Clinically Important Difference for the Ocular Surface Disease Index. Archives of Ophthalmology, 128, 94-101. https://doi.org/10.1016/S1542-0124(12)70081-2

[32] Lemp, M.A., Baudouin, C., Baum, J., Dogru, M., Foulks, N.G., Kinoshita, S., Laibson, P., McCulley, J., Murube, J. and Pflugfelder, C.S. (2007) The Definition and Classification of Dry Eye Disease: Report of the Definition and Classification Subcommittee of the International Dry Eye Workshop (2007). The Ocular Surface, 5, 75-92. https://doi.org/10.1016/S1542-0124(12)70081-2

[33] Salami, M.O., Bains, S., Shankar, S., Thangarajah, R. and Sogbesan, E. (2021) Evaluation of Masked Associated Dry Eyes Using AS-OCT Tear Meniscus Parameters and OSDI Scores. Investigative Ophthalmology \& Visual Science, 62, 1254.

[34] Foulks, G.N. (2007) The Correlation between the Tear Film Lipid Layer and Dry Eye Disease. Survey of Ophthalmology, 52, 369-374.

https://doi.org/10.1016/j.survophthal.2007.04.009

[35] Aksoy, M. and Simsek, M. (2021) Evaluation of Ocular Surface and Dry Eye Symptoms in Face Mask Users. Eye \& Contact Lens, 47, 555-558. https://doi.org/10.1097/ICL.0000000000000831

[36] Tomlinson, A., Madden, L.C. and Simmons, P.A. (2013) Effectiveness of Dry Eye Therapy under Conditions of Environmental Stress. Current Eye Research, 38, 229236. https://doi.org/10.3109/02713683.2012.757323

[37] Potvin, R., Makari, S. and Rapuano, C.J. (2015) Tear Film Osmolarity and Dry Eye Disease: A Review of the Literature. Clinical Ophthalmology, 9, 2039-2047. https://doi.org/10.2147/OPTH.S95242

[38] Scalinci, S.Z., Pacella, E. and Battagliola, E.T. (2021) Prolonged Face Mask Use Might Worsen Dry Eye Symptoms. Indian Journal of Ophthalmology, 69, 1508-1510. https://doi.org/10.4103/ijo.IJO 264120

[39] Alves, M., Novaes, P., Morraye, M., Reinach, P.S. and Rocha, E.M. (2014) Is Dry Eye an Environmental Disease? Arquivos brasileiros de oftalmologia, 77, 193-200. https://doi.org/10.5935/0004-2749.20140050

[40] Wolkoff, P., Skov, P., Franck, C. and Petersen, L.N. (2003) Eye Irritation and Environmental Factors in the Office Environment-Hypotheses, Causes and a Physiological Model. Scandinavian Journal of Work, Environment \& Health, 29, 411-430. https://doi.org/10.5271/sjweh.748

[41] Nakamura, S., Shibuya, M., Nakashima, H., Hisamura, R., Masuda, N., Imagawa, T., Uehara, M. and Tsubota, K. (2007) Involvement of Oxidative Stress on Corneal Epithelial Alterations in a Blink-Suppressed Dry Eye. Investigative Ophthalmology \& Visual Science, 48, 1552-1558. https://doi.org/10.1167/iovs.06-1027

[42] Chen, X., Gallar, J., Pozo, M.A., Baeza, M. and Belmonte, C. (1995) $\mathrm{CO}_{2}$ Stimulation of the Cornea: A Comparison between Human Sensation and Nerve Activity in Polymodal Nociceptive Afferents of the Cat. The European Journal of Neuroscience, 7, 1154-1163. https://doi.org/10.1111/j.1460-9568.1995.tb01105.x

[43] Sen, C.K. and Packer, L. (1996) Antioxidant and Redox Regulation of Gene Transcription. FASEB Journal, 10, 709-720. https://doi.org/10.1096/fasebj.10.7.8635688 
[44] Xia, C., Meng, Q., Liu, L.Z., Rojanasakul, Y., Wang, X.R. and Jiang, B.H. (2007) Reactive Oxygen Species Regulate Angiogenesis and Tumor Growth through Vascular Endothelial Growth Factor. Cancer Research, 67, 10823-10830. https://doi.org/10.1158/0008-5472.CAN-07-0783

[45] Fialkow, L., Wang, Y. and Downey, G.P. (2007) Reactive Oxygen and Nitrogen Species as Signaling Molecules Regulating Neutrophil Function. Free Radical Biology \& Medicine, 42, 153-164. https://doi.org/10.1016/j.freeradbiomed.2006.09.030

[46] Mastropasqua, L., Lanzini, M., Brescia, L., D’Aloisio, R., Nubile, M., Ciancaglini, M., D'Amario, C., Agnifili, L. and Mastropasqua, R. (2021) Face Mask-Related Ocular Surface Modifications during COVID-19 Pandemic: A Clinical, in Vivo Confocal Microscopy, and Immune-Cytology Study. Translational Vision Science \& Technology, 10, Article No. 22. https://doi.org/10.1167/tvst.10.3.22

[47] McMonnies C.W. (2007) Incomplete Blinking: Exposure Keratopathy, Lid Wiper Epitheliopathy, Dry Eye, Refractive Surgery, and Dry Contact Lenses. Contact Lens \& Anterior Eye, 30, 37-51. https://doi.org/10.1016/j.clae.2006.12.002

[48] Hong, N., Yu, W., Xia, J., Shen, Y., Yap, M. and Han, W. (2020) Evaluation of Ocular Symptoms and Tropism of SARS-CoV-2 in Patients Confirmed with COVID-19. Acta Ophthalmologica, 98, e649-e655. https://doi.org/10.1111/aos.14445

[49] Schaumberg, D.A., Uchino, M., Christen, W.G., Semba, R.D., Buring, J.E. and Li, J.Z. (2013) Patient Reported Differences in Dry Eye Disease between Men and Women: Impact, Management, and Patient Satisfaction. PLoS ONE, 8, Article ID: e76121. https://doi.org/10.1371/journal.pone.0076121

[50] Matossian, C., McDonald, M., Donaldson, K.E., Nichols, K.K., MacIver, S. and Gupta, P.K. (2019) Dry Eye Disease: Consideration for Women's Health. Journal of Women's Health, 28, 502-514. https://doi.org/10.1089/jwh.2018.7041

[51] Vehof, J., Sillevis Smitt-Kamminga, N., Nibourg, S.A. and Hammond, C.J. (2018) Sex Differences in Clinical Characteristics of Dry Eye Disease. The Ocular Surface, 16, 242-248. https://doi.org/10.1016/j.jtos.2018.01.001

[52] Mehra, D. and Galor, A. (2020) Digital Screen Use and Dry Eye: A Review. AsiaPacific Journal of Ophthalmology, 9, 491-497. https://doi.org/10.1097/APO.0000000000000328

[53] Akkaya, S., Atakan, T., Acikalin, B., Aksoy, S. and Ozkurt, Y. (2018) Effects of LongTerm Computer Use on Eye Dryness. Northern Clinics of Istanbul, 5, 319-322. https://doi.org/10.14744/nci.2017.54036

[54] Xu, W.H., Qu, J.Y., Chen, Y.L. and Zhang, M.C. (2018) Influence of Blue Light from Visual Display Terminals on Human Ocular Surface. Chinese Journal of Ophthalmology, 54, 426-431.

[55] Sağdık, H.M., Ugurbas, S.H., Can, M., Tetikoğlu, M., Ugurbas, E., Uğurbaş, S.C., Alpay, A. and Uçar, F. (2013) Tear Film Osmolarity in Patients with Diabetes Mellitus. Ophthalmic Research, 50, 1-5. https://doi.org/10.1159/000345770

[56] Zhang, X., Zhao, L., Deng, S., Sun, X. and Wang, N. (2016) Dry Eye Syndrome in Patients with Diabetes Mellitus: Prevalence, Etiology, and Clinical Characteristics. Journal of Ophthalmology, 2016, Article ID: 8201053.

https://doi.org/10.1155/2016/8201053 